\begin{tabular}{|c|c|c|c|c|}
\hline \multirow[b]{2}{*}{ Fraction } & \multirow{2}{*}{$\begin{array}{c}\begin{array}{c}\text { Liver } \\
\text { (Ludewig } \\
\text { and Chanu- } \\
\text { tin) }\end{array} \\
\begin{array}{c}\text { Total } \\
\text { activity } \\
\text { (per cent) }\end{array}\end{array}$} & \multicolumn{3}{|c|}{$\begin{array}{l}\text { Cardiac muscle } \\
\text { (Moyle) }\end{array}$} \\
\hline & & $\begin{array}{c}\text { Total } \\
\text { activity } \\
\text { (per cent) }\end{array}$ & $\begin{array}{c}\text { Total } \\
\text { dry wt. } \\
\text { (per cent) }\end{array}$ & $\begin{array}{l}\text { Speciflc } \\
\text { activity }\end{array}$ \\
\hline \multirow{3}{*}{$\begin{array}{l}\text { Homogenate } \\
\text { (a) Residue } \\
\text { (b) Large } \\
\text { particles } \\
\text { (c) Supernatant } \\
a+b+c\end{array}$} & $\begin{array}{r}100 \\
15\end{array}$ & $\begin{array}{r}100 \\
44\end{array}$ & \multirow{3}{*}{$\begin{array}{l}100 \\
9 \cdot 3\end{array}$} & \multirow{3}{*}{0.2} \\
\hline & $\begin{array}{r}62 \\
7\end{array}$ & ${ }_{56}^{2}$ & & \\
\hline & 84 & 102 & & \\
\hline
\end{tabular}

nuclear residue, (b) sarcosomes and (c) sarcoplasm. Rhodanese activity was estimated by the method of Cosby and Sumner. A comparison of the activity of the homogenate and the tissue fractions showed that the sarcosomes contained no rhodanese, the total activity of the muscle being only about 10 per cent that of liver (per unit weight).

Cleland and Slater ${ }^{2}$ have reported a parallel situation in the distribution of myokinase, which occurs in the sarcoplasm of cardiac muscle but in the mitochondria of liver?

So, although the 'Iarge granules' from liver and heart muscle show similarity in being the site of respiratory enzyme systems, they are not completely identical units differing only slightly in morphology from tissue to tissue. In their diverse non-respiratory functions they may take very different roles in the metabolism of their respective tissues.

I wish to thank Dr. M. Dixon for valuable advice, and the Medical Research Council for a grant.

Department of Biochemistry, JENNIFER M. MOYLE

University of Cambridge. April 22.

${ }^{1}$ Green, D. E., "Enzymes and Enzyme Sy stems"' (Harvard, 1951). Hogeboom, G. H., Fed. Pros., 10,640 (1951). 'Lehninger, A. L., (1951).

K. W. and Slater, E. C., Biochem J. 53, 547 (1953).

${ }^{3}$ Paul, M. H., Fuld, M., and Sperling, E., Proc. Soc. Exp. Biol. Med., 79, (1952).

- Ludewig, S., and Chanutin, A., Arch. Biochem., 29, 441 (1950).

${ }^{5}$ Hogeboom, G. H., Schneider, W. C., and Pallade, G. E., J. Biol. Chem., 172, 619 (1948).

${ }^{\circ}$ Cosby, E. L., and Sumner, J. B., Arch. Biochem., 7, 457 (1945).

${ }^{7}$ Kielley, W. W., and Kielley, R. K., J. Biol. Chem., 191, 485 (1951).

\section{Activation of Fumaric Hydrogenase by Ferrous Ions}

Fischer et al. ${ }^{1}$ described an enzyme from yeast which catalyses the reduction of fumarate to succinate by leuco-dyestuffs. They showed that the coenzyme is flavine adenine dinucleotide.

It has now been found that addition of flavine adenine dinucleotide does not fully restore the activity of this enzyme after dialysis and adsorption on alumina $C_{\gamma}$, but that addition of ferrous ions is also necessary.

Thunberg tubes contained: $0.5 \mathrm{ml}$. $0.05 \mathrm{M}$ phosphate buffer $p \mathrm{H} 7.4$ and $1 \mathrm{ml} .0 \cdot 03 M$ fumarate. In stopper : $0.5 \mathrm{ml} .0 .0002 M$ janus green reduced with $0.2 \mathrm{mgm}$. hydrosulphite. Gas, nitrogen. activation of Fumartc Hydrogenase

\begin{tabular}{|c|c|}
\hline \multicolumn{1}{|c|}{ Additions } & Oxidation time (min.) \\
\hline Nil & $>25$ \\
$\mathrm{Fe}^{++}$ & $>25$ \\
Enzyme & $10 \frac{1}{2}$ \\
Enzyme $+\mathrm{Fe}^{++}$ & $1 \frac{1}{2}$ \\
\hline
\end{tabular}

Additions : $1 \mathrm{ml}$. enzyme (dialysed in the presence of flavine adenine dinucleotide); $0.2 \mathrm{ml}$. $0.01 M$ $\mathrm{FeSO}_{4}$. Other metals such as $\mathrm{Mn}++$ are ineffective. Keilin-Hartree preparations of succinic dehydrogenase from heart muscle also lose activity on dialysis; addition of ferrous ions enables the reduction of fumarate to take place. It would appear, therefore, that ferrous ions are required for electron transfer in succinate-fumarate systems.

K. HARRISON

Department of Biochemistry, Cambridge. May 4.

1 Fischer, F. G., et al., Ann. Chem., 552, 203 (1942).

\section{Chromaffin Bodies of Various Species of Dogfish}

IN lower vertebrates, structures homologous to the adrenal gland of higher vertebrates remain separated throughout life. In the dogfish, for example, an unpaired inter-renal body representing the adrenal cortex is quite separate from the chromaffin bodies: or rudimentary adrenal medulla. Extracts of each component can therefore be made without contamination by the other part.

Since workers in both our departments are interested in the biosynthesis of adrenaline, we have investigated by chromatographic and biological methods the amines present in the chromaffin bodies: of Scylliorhinus canicula and stellaris (in Bari), Squalus acanthias and Mustelis canis (in Dundee) and Torpedo marmorata (in both Bari and Dundee). Our pooled results are shown in the accompanying table. Large quantities of adrenaline and noradrenaline are contained in these extracts; but hydroxytyramine, dihydroxyphenylalanine, dihydroxyphenylserine, tyramine and octopamine ( $p$-norsynephrine). are not present in detectable amounts. Concentrated extracts of the livers, kidneys, intestinal tract, and inter-renal bodies of these dogfish species do not contain significant amounts of any of the seven. substances mentioned.

AMINES ( $\mu$ GM./GM.) PRhShiNT IN THE ChromafFin Bodies OF DOGHISH

\begin{tabular}{|l|c|c|c|}
\hline \multicolumn{1}{|c|}{ Species } & Adrenaline & Noradrenaline & $\begin{array}{c}\text { Noradrenaline } \\
\text { (per cent in } \\
\text { total) }\end{array}$ \\
\hline $\begin{array}{l}\text { Squalus acanthias } \\
\text { Mustelis canis }\end{array}$ & 900 & 2,400 & 73 \\
$\begin{array}{l}\text { Scylliorhinus } \\
\text { canicula }\end{array}$ & 1,000 & 2,200 & 69 \\
$\begin{array}{l}\text { Scylliorhinus } \\
\text { stellaris }\end{array}$ & 1,150 & 2,200 & 66 \\
$\begin{array}{l}\text { Torpedo marmor- } \\
\text { ata }\end{array}$ & 850 & 1,900 & 67 \\
\hline
\end{tabular}

These results do not assist in advancing the method by which adrenaline and noradrenaline are formed in the body. However, it is evident that even the pathways through dihydroxyphenylalanine and hydroxytyramine, or through tyramine and $p$-norsynephrine, must be considered doubtful.

\section{M. SHEPHERD}

G. B. West

Department of Pharmacology and Therapeutics,

University of St. Andrews Medical School, Dundee.

V. ERspamer

Department of Pharmacology, University of Bari,

Italy. April 29. 